\title{
NURSING WORKLOAD AT A GASTROENTEROLOGY UNIT ${ }^{1}$
}

Marcia Raquel Panunto ${ }^{2}$ Edinêis de Brito Guirardello

Panunto MR, Guirardello EB. Nursing workload at a gastroenterology unit. Rev Latino-am Enfermagem 2009 novembro-dezembro; 17(6):1009-14.

One of the biggest challenges nurses face is the need to justify the quantity and quality of staff for care delivery. For this, management instruments are available which help them to determine the staff needed in the nursing team. This descriptive study aims to evaluate the nursing workload at a specialized clinical and surgical gastroenterology unit. To collect data, the Nursing Activities Score (NAS) was used during 30 consecutive days, with 1080 comments, obtained from the records of 149 patients. The mean NAS score was 34.9\% and, considering that each point of NAS corresponds to 0.24 hour, on the average, 8.4 hours of nursing care were required within 24 hours. This means that this profile is of patients who demand intermediate and semi-intensive care, which suggests that the NAS study can be used to evaluate the workload of nurses at that unit.

DESCRIPTORS: workload; nursing assessment; nursing staff

\section{CARGA DE TRABAJO DE ENFERMERÍA EN UNA UNIDAD DE GASTROENTEROLOGÍA}

Uno de los mayores desafíos enfrentados por el enfermero se refiere a la necesidad de justificar la cantidad y calidad de personal que se necesita en una unidad para la prestación de asistencia. Para eso, dispone de herramientas administrativas que auxilian en la determinación del personal necesario en el equipo de enfermería. Se trata de un estudio descriptivo, que tuvo por objetivo evaluar la carga de trabajo de enfermería en una unidad clínica y quirúrgica, especializada en gastroenterología. Para la recolección de datos, se utilizó el Nursing Activities Score (NAS) por 30 días consecutivos, totalizando 1.080 observaciones, obtenidas de los registros de 149 pacientes. El promedio de la puntuación del NAS fue de 34,9\% y, considerando que cada punto del NAS corresponde a 0,24h, fueron requeridas, en promedio, 8,4 horas de enfermería para la asistencia en las 24h. Eso significa que el perfil de esos pacientes corresponde al de aquellos que requieren cuidados intermediarios y semi-intensivos, lo que sugiere que el NAS puede ser utilizado para evaluar la carga de trabajo de enfermería en la referida unidad.

DESCRIPTORES: carga de trabajo; evaluación en enfermería; personal de enfermería

\section{CARGA DE TRABALHO DE ENFERMAGEM EM UMA UNIDADE DE GASTROENTEROLOGIA}

Um dos maiores desafios enfrentados pelo enfermeiro refere-se à necessidade de justificar o quantitativo e qualitativo de pessoal para a prestação da assistência. Para isso, dispõe de ferramentas gerenciais que auxiliam na determinação do pessoal necessário na equipe de enfermagem. Trata-se, aqui, de estudo descritivo, que objetivou avaliar a carga de trabalho de enfermagem em uma unidade clínica e cirúrgica, especializada em gastroenterologia. Para a coleta de dados, utilizou-se o Nursing Activities Score (NAS) por 30 dias consecutivos, totalizando 1080 observações, obtidas do registro de 149 pacientes. A média da pontuação do NAS foi de $34,9 \%$ e, considerando que cada ponto do NAS corresponde a 0,24h, foram requeridas, em média, 8,4 horas de enfermagem na assistência nas 24h. Isso significa que o perfil desses pacientes corresponde ao daqueles que requerem cuidados intermediários e semi-intensivos, o que sugere que o NAS pode ser utilizado para avaliar a carga de trabalho de enfermagem na referida unidade.

DESCRITORES: carga de trabalho; avaliação em enfermagem; recursos humanos de enfermagem 


\section{INTRODUCTION}

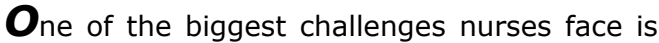
the need to justify the quantity and quality of staff for care delivery to clients. This process can result in conflicts, however, as the growing need to decrease costs and increase nursing service delivery arouses questions about institutions' nursing staff ${ }^{(1)}$.

For service management to justify a given nursing staff, nowadays, nurses have management tools at their disposal to rank patients in terms of care complexity level, consequently helping to determine the nursing staff needed for quality care delivery. These include instruments developed in Brazil for adult hospitalized patients ${ }^{(2-6)}$, for residency nursing ${ }^{(7)}$ and for pediatric patients ${ }^{(8)}$, as well as others validated for the Brazilian culture, such as the Therapeutic Intervention Scoring System (TISS-28) ${ }^{(9)}$ and the Nursing Activities Score (NAS) ${ }^{(10)}$.

Differently from the above instruments, the NAS assesses the number of nursing hours spent per patient during one work shift, based on its total score ${ }^{(10-}$ 11). It contains 23 items, which cover basic activities (monitoring, medication, hygiene procedures, administrative tasks, among others), mechanical ventilation, cardiovascular, renal, neurological and metabolic support, besides specific interventions. The sum of these items shows the time nursing activities consume in 24-hour patient care delivery. Scores can range from zero to 100 (\%) or more, which can mean that more than one nursing professional was needed to deliver care to the patient on a given day ${ }^{(11)}$.

Although the NAS was constructed for application to patients from critical care units, it is considered useful to assess nursing workload at tertiary and quaternary hospital units, where clients' care complexity level is high. It should be reminded that the NAS score does not depend on patient severity, as its construction and validation were based on nursing activities ${ }^{(11)}$.

The Patient Classification System $(\mathrm{PCS})^{(2,4)}$ has been used for staff dimensioning at hospitalization units, classifying patients in care groups or categories. While this type of tool identifies the patient's level of complexity, the NAS permits measuring the workload in terms of direct and indirectly related nursing care hours. However, studies using the NAS have been applied to ICU patients, evidencing its reliability to assess workloads for patients who require intensive care $^{(12-15)}$.
The choice of a patient classification instrument to identify the workload should not only be based on its specific indication, but should also take into account an institution's care delivery dynamics and complexity.

In view of difficulties to apply an instrument that permits classifying patients into care complexity levels, this research aims to measure the nursing workload at a clinical and surgical unit like gastroenterology.

\section{METHOD}

This descriptive study was carried out at a gastroenterology unit of a teaching hospital in the interior of São Paulo state. The unit is subdivided into two nursing wards, gastroclinic and gastrosurgery, totaling 36 beds, eight for the gastroclinic and 28 for gastrosurgery.

To collect data, the NAS was used to measure the nursing workload, besides a form to characterize the patients' demographic and clinical data. For the study, all adult patients attended at the unit during the research period were considered.

Approval for the research was obtained from the institution's Ethics Committee (Process No 758/ 2007), requesting dispensation from the signing of the free and informed consent term (FICT). This request was justified to the Ethics Committee as the assessment of patient care demands is considered a daily nursing activity and because the patient was not submitted to any other procedure in function of the application of the instrument.

Before data collection, the instrument was submitted to a 15-day pretest to allow the researcher to become familiar with the tool and adapt some of its aspects to the patients' profile at the unit. The researcher herself collected the data during 30 consecutive days, from April 14th to May 14th 2008. Data were collected based on patient assessment, information in nursing notes and patient files, as well as verbal information provided by the nursing team which was not recorded in the files.

The collected data were transferred to a Microsoft ${ }^{\circledR}$ Excel worksheet and analyzed through SPSS $^{\circledR} 16.0$ for Windows. Frequency tables were elaborated for the categorical variables and descriptive statistics (mean, standard deviation, median, minimum and maximum) for the continuous variables. The Chi-square test was used to check for association 
between the posts and the categorical variables, and Fisher's exact test was applied when expected levels were below five. Mann-Whitney's non-parametric test was used to compare the wards in terms of categorical variables. The significance level was set at $5 \%$, i.e. $p$ $\leq 0.05$.

\section{RESULTS}

The NAS was applied during 30 consecutive days to the 36 beds at the gastroenterology unit (gastroclinic and gastrosurgery nursing wards), totaling 1080 observations, obtained from 149 patients' records. To measure the workload at the unit, the researcher decided to consider the bed, independently from the subject occupying it. Hence, the collected data followed bed occupation dynamics.
In the group of 149 patients, $56.4 \%$ came from gastrosurgery and $43.6 \%$ from the gastroclinic. Most cases referred to elective hospitalization. Mean age at the unit was 50 years $(\min =18$ and $\max =90)$, and patients' mean hospitalization time was 7 days ( $\min =1$ and $\max =67$ ). In this group, $59.7 \%$ were men and $40.3 \%$ women.

Data indicated that, at the gastroclinical ward, male patients with liver diseases predominated when compared with the gastrosurgery ward. On the other hand, in gastrosurgery, most patients were hospitalized for less than five days and were submitted to surgical treatment.

The workload according to the NAS, including mean and median scores for the unit and wards, is shown in Table 1. Minimum scores equalling zero mean that the bed was empty during a data collection day.

Table 1 - NAS workload score at gastroenterology unit (\%). Campinas, 2008

\begin{tabular}{lccccccc}
\hline \multicolumn{1}{c}{ Unit } & N & Mean & SD & Median & Minimum & Maximum & p value* \\
\hline Gastroclinic & 540 & 37.2 & 23.9 & 35.6 & 0 & 136 \\
Gastrosurgery & 540 & 32.6 & 20 & 29.9 & 0 & 113 \\
Total & 1080 & 34.9 & 22.2 & 33.7 & 0 & 136 \\
\hline
\end{tabular}

*Mann-Whitney

The observation of mean NAS scores per bed revealed that four beds, with generators, located in two rooms at the gastroclinical ward, obtained the highest mean workload scores, ranging between 44.9 and $68.3 \%$, when compared with other beds at the unit. On the other hand, the four beds at the gastrosurgery ward, with the same characteristic, scored equal or lower than other beds at this ward.

As the NAS permits identifying nursing activities during 24-hour patient care, the recording frequency of instrument items and subitems can be calculated (Table 2).

Table 2 - Frequency of item and subitem performance of Nursing Activities Score. Campinas, 2008

\begin{tabular}{|c|c|c|}
\hline Items and subitems & $\mathbf{n}$ & $\%$ \\
\hline \multicolumn{3}{|l|}{ 1. Monitoring and titration } \\
\hline 1a. Hourly vital signs, regular registration and calculation of fluid balance. (4.5 pts) & 840 & 77.8 \\
\hline 1b. Present at bedside and continuous observation or active for $2 \mathrm{hrs}$ or more. (12.1 pts) & 83 & 7.7 \\
\hline 1c. Present at bedside and active for 4 hrs or more. (19.6 pts) & 5 & 0.5 \\
\hline 2. Laboratory, biochemical and microbiological investigations. (4.3 pts) & 276 & 25.6 \\
\hline 3. Medication, vasoactive drugs excluded. (5.6 pts) & 916 & 84.8 \\
\hline \multicolumn{3}{|l|}{ 4. Hygiene procedures } \\
\hline 4a. Performing hygiene procedures. (4.1 pts) & 812 & 75.2 \\
\hline 4b. The performance of hygiene procedures took more than 2 hrs. (16.5 pts) & 90 & 8.3 \\
\hline 4c. The performance of hygiene procedures took more than $4 \mathrm{hrs}$. (20.0 pts) & 2 & 0.2 \\
\hline 5. Care of drains - All (except gastric tube). (1.8 pts) & 244 & 22.6 \\
\hline \multicolumn{3}{|l|}{ 6. Mobilization and positioning } \\
\hline 6a. Performing procedure(s) up to three times per $24 \mathrm{hrs}$. (5.5 pts) & 71 & 6.6 \\
\hline 6b. Performing procedure(s) more frequently than 3 times per 24 hrs, or with two nurses, any frequency. (12.4 pts) & 45 & 4.2 \\
\hline 6c. Performing procedure with three or more nurses, any frequency. (17.0 pts) & 3 & 0.3 \\
\hline
\end{tabular}




\begin{tabular}{|c|c|c|}
\hline Items and subitems & $\mathbf{n}$ & $\%$ \\
\hline \multicolumn{3}{|l|}{ 7. Support and care of relatives and patient } \\
\hline 7a. Support and care of either relatives or patient requiring full dedication for about $1 \mathrm{hr}$ in any shift. ( $4.0 \mathrm{pts})$ & 881 & 81.6 \\
\hline 7b. Support and care of either relatives or patient requiring full dedication for 3 hrs or more in any. ( $32.0 \mathrm{pts}$ ) & 46 & 4.3 \\
\hline \multicolumn{3}{|l|}{ 8. Administrative and managerial tasks } \\
\hline $\begin{array}{l}\text { 8a. Performing routine tasks such as processing of clinical data, ordering examinations, professional exchange of } \\
\text { information. (4.2 pts) }\end{array}$ & 606 & 56.1 \\
\hline 8b. Performing administrative and managerial tasks requiring full dedication for about 2 hrs in any shift. (23.2 pts) & 328 & 30.4 \\
\hline $\begin{array}{l}\text { 8c. Performing administrative and managerial tasks requiring full dedication for about } 4 \text { hrs or more of the time in } \\
\text { any shift. ( } 30.0 \text { pts) }\end{array}$ & 5 & 0.5 \\
\hline $\begin{array}{l}\text { 9. Respiratory support: any form of mechanical ventilation/assisted ventilation ; supplementary oxygen by any } \\
\text { method. ( } 1.4 \mathrm{pts})\end{array}$ & 74 & 6.9 \\
\hline 10. Care of artificial airways. (1.8 pts) & 45 & 4.2 \\
\hline 11. Treatment for improving lung function. (4.4 pts) & 298 & 27.6 \\
\hline 12. Vasoactive medication, disregard type and dose. (1.2 pts) & 21 & 1.9 \\
\hline 13. Intravenous replacement of large fluid losses. ( $2.5 \mathrm{pts}$ ) & 0 & 0 \\
\hline 14. Left atrium monitoring. (1.7 pts) & 0 & 0 \\
\hline 15. Cardiopulmonary resuscitation in the past period of $24 \mathrm{hrs}$. (7.1 pts) & 3 & 0.3 \\
\hline 16. Hemofiltration techniques. Dialysis techniques. (7.7 pts) & 10 & 0.9 \\
\hline 17. Quantitative urine output measurement. (7.0 pts) & 422 & 39.1 \\
\hline 18. Measurement of intracranial pressure. (1.6 pts) & 0 & 0 \\
\hline 19. Treatment of complicated metabolic acidosis/alkalosis. (1.3 pts) & 6 & 0.6 \\
\hline 20. Intravenous hyperalimentation. ( $2.8 \mathrm{pts})$ & 49 & 4.5 \\
\hline 21. Enteral feeding through gastric tube or other gastrointestinal route. (1.3 pts) & 64 & 5.9 \\
\hline 22. Specific intervention(s) in the intensive care unit. (2.8 pts) & 41 & 3.8 \\
\hline 23. Specific interventions outside the intensive care unit. (1.9 pts) & 199 & 18.4 \\
\hline
\end{tabular}

In items $1,4,6,7$ and 8 , only one subitem can be scored

\section{DISCUSSION}

Study data appoint the predominance of male patients, submitted to surgical treatment and hospitalized for less than five days. The greatest hospitalization turnover was found at the gastrosurgical ward.

At that ward, most patients were admitted for surgical patients, but patients for clinical treatment were also attended, as some of these, in the late postoperative period, are hospitalized for clinical compensation. At the gastroclinic, on the other hand, these percentages did not differ because the unit offers beds for clinical as well as surgical care.

According to the NAS, the mean workload at the gastroenterology unit was $34.9 \%$. The comparison between both wards showed a difference, with a higher score for the gastroclinical than for the gastrosurgery ward. These results could not be compared with other studies, however, as the application of this instrument has been restricted to intensive care units, but some of the reasons for these differences can be due to the level of dependence and clinical procedures performed. Studies carried out at ICU appoint a higher mean workload ${ }^{(10,12-15)}$ than what was found in this research, although one of those studies $^{(14)}$ reported a lower minimum NAS score than the mean score found at the gastroenterology unit.

The gastroclinical ward obtained the highest mean workload scores, for beds with generators as well as for other beds at the ward, which means that these beds were occupied by patients with greater nursing care demands. It is interesting to highlight that, in gastrosurgery, some of the beds not equipped for care delivery to patients with high care demands scored the same or higher than beds with generators.

The most frequent NAS items were: 1a. Hourly vital signs, regular registration and calculation of fluid balance; 3. Medication, vasoactive drugs excluded; 4a. Performing hygiene procedures; 7a. Support and care of either relatives or patient requiring full dedication for about $1 \mathrm{hr}$ in any shift and $8 \mathrm{a}$. Performing routine tasks.

Unscored items are relatived to activities performed at a specialized intensive care unit ${ }^{(14-15)}$, according to expectations for the gastroenterology patient profile.

To obtain NAS workload results comparable with the total nursing hours recommended by the Brazilian Federal Nursing Council (COFEN) ${ }^{(16)}$, 
according to the type of care the patient demands, the NAS score needs to be transformed into hours.

Each NAS point is equivalent to $0.24 \mathrm{hr}^{(14)}$ and, on the average, $34.9 \%$ of the workload at the gastroenterology unit was measured, 8.4 hours of nursing service were delivered during 24-hour care. In view of recommendations established in COFEN resolution No 293/2004(16), the obtained score evidences a profile of patients demanding intermediary and semi-intensive care, suggesting that the NAS can be used to assess the nursing workload at that unit.

\section{CONCLUSIONS}

This research permitted measuring the nursing workload at a specialized clinical and surgical gastroenterology care unit. The workload, according to the NAS, corresponded to $34.9 \%$ for the unit, with differences between the nursing wards, i.e. $37.2 \%$ for the gastroclinic and $32.63 \%$ for the gastrosurgical ward.

The total score resulted in an average 8.4 hours of nursing care during 24 hours, corresponding to the profile of patients demanding intermediary and semi-intensive care. Although the NAS is applicable to ICU, its utility to determine the nursing workload at the study unit could be demonstrated.

In view of these results, the importance of nurses assessing the nursing workload at their unit is highlighted, using instruments for this goal, either to make the nursing work process more oriented to patient demands or to help nurses to administer the staff in hospital service management.

As this was the first experience of using the NAS at a clinical and surgical unit, the researchers recommend its application in other studies with the same patient profile and hospital reality, as well as its validation for other than intensive care units.

\section{REFERENCES}

1. Gaidzinski RR, Fugulin FMT, Castilho V. Dimensionamento de pessoal de enfermagem em instituições de saúde. In: Kurcgant $P$, coordenador. Gerenciamento em Enfermagem. Rio de Janeiro (RJ): Guanabara Koogan; 2005. p .127-37.

2. Fugulin FMT, Gaidzinski RR, Kurcgant P. Sistema de classificação de pacientes: identificação do perfil assistencial dos pacientes das unidades de internação do HU-USP. Rev Latino-am Enfermagem 2005 janeiro-fevereiro; 13(1):72-8. 3. Santos F, Rogenski NMB, Baptista CMC, Fugulin FMT. Sistema de classificação de pacientes: proposta de complementação do instrumento de Fugulin et al. Rev Latinoam Enfermagem 2007 setembro-outubro; 15(5):980-5.

4. Perroca MG, Gaidzinski RR. Sistema de classificação de pacientes: construção e validação de um instrumento. Rev Esc Enferm USP 1998; 32(2):153-68.

5. Hokama CSM, Serrano CDBH. Sistema de classificação de pacientes (SCP) - ENFSCORE. In: Bork AMT, organizador. Enfermagem de excelência: da visão à ação. Rio de Janeiro (RJ): Guanabara Koogan; 2003. p. 101-10.

6. Martins EAP, Haddad MCL. Validação de um instrumento que classifica os pacientes em quatro graus de dependência do cuidado de enfermagem. Rev Latino-am Enfermagem 2000 abril; 8(2):74-82.

7. Dal Ben LW. Instrumento para dimensionar horas diárias de assistência de enfermagem residencial [dissertação]. São Paulo (SP): Escola de Enfermagem/USP; 2000.

8. Dini AP. Sistema de classificação de pacientes pediátricos: construção e validação de instrumento [dissertação]. Campinas (SP): Universidade Estadual de Campinas; 2007. 9. Nunes B. Tradução para o português e validação de um instrumento de medida de gravidade em UTI: Therapeutic Intervention Scoring System-28 (TISS-28) [dissertação]. São Paulo (SP): Escola de Enfermagem/USP; 2000.

10. Queijo AF. Tradução para o português e validação de um instrumento de medida de carga de trabalho de enfermagem em unidade de terapia intensiva: Nursing Activities Score (NAS) [dissertação]. São Paulo (SP): Escola de Enfermagem/ USP; 2002.

11. Miranda DR, Nap R, Rijk A, Schaufeli W, Iapichino G. Nursing Activities Score. Crit Care Med 2003; 31(2):374-82.

12. Balsanelli AP, Cunha ICKO, Whitaker IY. Estilos de liderança de enfermeiros em unidade de terapia intensiva: associação com perfil pessoal, profissional e carga de trabalho. Rev. Latino-Am. Enfermagem [periódico na Internet]. 2009 Fev [citado 2009 Jun 02] ; 17(1): 2833. Disponível em: http://www.scielo.br/scielo.php? script $=$ sci_arttext\&pid=S0104-11692009000 $100005 \&$ Ing $=p t$. doi: $10.1590 /$ S0104-11692009000 100005 .

13. Sousa CR, Gonçalves LA, Toffoleto MC, Leão K, Padilha KG. Preditores da demanda de trabalho de enfermagem para idosos internados em unidade de terapia intensiva. Rev. LatinoAm. Enfermagem [periódico na Internet]. $2008 \mathrm{Abr}$ [citado 2009 Jun 02] ; 16(2):218-23. Disponível em: http:// www.scielo.br/scielo.php?script $=$ sci_arttext\&pid $=$ S0104$11692008000200008 \&$ Ing $=$ pt. doi: 10.1590/S010411692008000200008 .

14. Conishi RMY. Avaliação do NAS - Nursing Activities Score - como instrumento de carga de trabalho de enfermagem em uma UTI geral adulto [dissertação]. São Paulo (SP): Escola de Enfermagem/ USP; 2005.

15. Gonçalves LA. Fatores associados à carga de trabalho 
de enfermagem em uma unidade de terapia intensiva de adultos no primeiro dia de internação [dissertação]. São Paulo (SP): Escola de Enfermagem/USP; 2006.

16. Conselho Federal de Enfermagem [Página na internet]. Resolução 293/2004. Fixa e estabelece parâmetros para o dimensionamento de pessoal de enfermagem nas unidades assistenciais das instituições de saúde e assemelhados [acesso em 29 fev 2008]. Disponível em: http:// www.portalcofen.com.br/2007/materias.asp?Article ID $=7121$ \&sectionI $=34$ 